\title{
Habitat-Specific Differences in Mercury Concentration in a Top Predator from a Shallow Lake
}

\author{
Matthew M. ChumChaL* ${ }^{1}$ \\ Department of Zoology, University of Oklahoma, Norman, Oklahoma 73019, USA \\ RAY W. DRENNER \\ Biology Department, Texas Christian University, Fort Worth, Texas 76129, USA \\ BRIAN FRY \\ Coastal Ecology Institute, Department of Oceanography and Coastal Studies, \\ Louisiana State University, Baton Rouge, Louisiana 70803, USA
}

K. David Hambright

Biological Station and Department of Zoology, University of Oklahoma, Norman, Oklahoma 73019, USA

\author{
Leo W. Newland
}

Biology Department, Texas Christian University, Fort Worth, Texas 76129, USA

\begin{abstract}
We conducted a survey of mercury contamination in largemouth bass Micropterus salmoides from Caddo Lake, Texas, and found that fish collected from forested wetland habitat had higher concentrations of mercury than those collected from open-water habitat. Habitat-specific differences in largemouth bass size, age, absolute growth rate, trophic position (based on $\delta^{15} \mathrm{~N}$ ), and horizontal food web position (based on $\delta^{13} \mathrm{C}$ ), characteristics known to influence mercury accumulation, did not explain the observed differences in mercury contamination. Rather, habitat-related differences in mercury concentration in a primary consumer, Mississippi grass shrimp Palaemonetes kadiakensis, indicated that food webs in forested wetland habitat were more contaminated with mercury than those in open-water habitat. Spatial variation in mercury contamination within lakes and elevated mercury concentrations in forested wetlands should be of special concern not only to researchers but also to public and environmental health officials dealing with mercury contamination in aquatic environments and human health risks associated with consumption of fish contaminated with mercury.
\end{abstract}

Since the industrial revolution $(\sim 1850)$, mercury deposition rates have increased by a factor of three to four (Swain et al. 1992), and some regions have experienced 11-fold increases (Schuster et al. 2002). The largest anthropogenic source of environmental mercury is coal-burning power plants (Pacyna and Pacyna 2002). Power plants release inorganic mercury into the atmosphere, where it resides until being deposited onto the earth's surface (Morel et al. 1998; Pacyna and Pacyna 2002). In aquatic ecosystems, bacteria convert inorganic mercury to highly toxic methylmercury (Morel et al. 1998; Ullrich et al. 2001). Organisms at the base of the food web, such as phytoplankton and periphyton, absorb methylmercury

\footnotetext{
* Corresponding author: m.m.chumchal@tcu.edu

1 Present address: Biology Department, Texas Christian University, Fort Worth, Texas 76129, USA.
}

Received January 9, 2007; accepted August 28, 2007

Published online January 14, 2008 directly from the water (Miles et al. 2001), whereas consumers, including fish, are primarily exposed to methylmercury through their diet (Hall et al. 1997; Tsui and Wang 2004). Methylmercury bioaccumulates in aquatic organisms (Wiener et al. 2003), and most of the mercury found in fish is methylmercury (Bloom 1992).

Humans are primarily exposed to methylmercury through consumption of mercury-contaminated fish (NRC 2000). Methylmercury is detrimental to human health; even low doses can damage the nervous and cardiovascular systems of humans (NRC 2000; Clarkson 2002). Fetuses are particularly sensitive to methylmercury, and prenatal exposure to low concentrations of methylmercury can cause developmental and cognitive problems (NRC 2000; Clarkson 2002). To better understand human exposure to mercury, we must first understand the ecological factors that regulate mercury accumulation in fish.

Fish in ecosystems with high net methylmercury production have elevated concentrations of mercury 
because more mercury is available for incorporation into the food web (Wiener et al. 2003). Wetlands are ecosystems in which the conversion of inorganic mercury to methylmercury is efficient due to biogeochemical properties (e.g., low $\mathrm{pH}$, low dissolved oxygen, high dissolved organic carbon) that support elevated activities of methylating bacteria and lead to the accumulation of mercury in sediments (Wiener et al. 2003; Driscoll et al. 2007).

Many biological characteristics of fish can also strongly influence mercury accumulation. For example, mercury concentrations in fish are positively correlated with fish size, age, and trophic position (TP; i.e., the vertical trophic level at which fish feed; Johnels et al. 1967; Cabana and Rasmussen 1994; McClain et al. 2006) and negatively correlated with fish growth rate (Rodgers 1996; Stafford and Haines 2001; Simoneau et al. 2005). Because pelagic food webs (i.e., those based on phytoplankton production) may be more contaminated with mercury than littoral or benthic food webs (i.e., those based on periphyton production; Lindqvist et al. 1991; Power et al. 2002; Gorski et al. 2003; Kidd et al. 2003), horizontal food web position (sensu Leibold et al. 1997) also influences mercury concentration in fish.

Within lakes, there is often spatial variation in fish mercury concentration (Munn and Short 1997; Cizdziel et al. 2002; Campbell et al. 2003a; Burger et al. 2004; Stafford et al. 2004; Simoneau et al. 2005). This is probably due to heterogeneity in methylmercury availability (Munn and Short 1997; Cizdziel et al. 2002; Campbell et al. 2003a; Stafford et al. 2004). However, most of these studies were not able to rule out habitat-specific differences in fish size, age, growth rate, $\mathrm{TP}$, and horizontal food web position, factors that could confound conclusions of heterogeneity in methylmercury availability (but see Campbell et al. 2003a, 2003b).

We conducted a survey of mercury contamination in largemouth bass Micropterus salmoides from Caddo Lake, located on the border of Texas and Louisiana. Largemouth bass collected from forested wetland habitat (sensu Cowardin et al. 1979), which is characterized by the presence of bald cypress Taxodium distichum, shallow depths (approximately $1 \mathrm{~m}$ ), and abundant aquatic vegetation, had higher concentrations of mercury than those collected from openwater habitat, which is deeper and contains less aquatic vegetation. We present these results and our investigation of mechanisms that may explain the observed patterns of habitat-specific mercury contamination in Caddo Lake largemouth bass. Habitat-specific differences in mercury contamination of largemouth bass would be expected if biological characteristics that influence mercury accumulation in fish or methylmercury availability differ between the two habitats. To distinguish between these alternatives, we compared largemouth bass size, age, absolute growth rate, TP (determined using $\delta^{15} \mathrm{~N}$ ), and horizontal food web position (determined using $\delta^{13} \mathrm{C}$ ) between the two habitat types. We also examined mercury concentrations in Mississippi grass shrimp Palaemonetes kadiakensis to determine whether there were habitatspecific differences in the mercury concentrations of organisms near the base of the food web, which would indicate differences in methylmercury availability (Lindqvist et al. 1991).

\section{Methods}

Study site.-Caddo Lake (Figure 1) has a surface area of approximately $107 \mathrm{~km}^{2}$ (Van Kley and Hine 1998). The western portion of the lake (approximately $40 \mathrm{~km}^{2}$; mostly in Texas) is shallow (average depth $<$ $1 \mathrm{~m}$; M.M.C., personal observation) and composed primarily of a forested wetland (hereafter, wetland) dominated by bald cypress, water elm Planera aquatica, and other aquatic vegetation, including fanwort Cabomba caroliniana, Brazilian waterweed Egeria densa, and yellow pond-lily Nuphar luteum (Van Kley and Hine 1998). More than half of the wetland is nonnavigable due to high densities of bald cypress and water elm; many of the remaining wetland areas are not navigable in the late summer and fall due to dense aquatic vegetation. The eastern portion of Caddo Lake (mostly in Louisiana) is primarily openwater habitat (average depth $=1.4 \mathrm{~m}$; maximum depth $=8.2 \mathrm{~m}$; Ensminger 1999). In the open-water habitat, submerged vegetation can be extensive in the summer months, but the area remains navigable throughout the year (M.M.C., personal observation). The wetland does not stratify, but some areas of the open water exhibit weak thermal stratification in June and July (Hartung 1983). From 2000 to 2004, lake elevation fluctuated by approximately $1.3 \mathrm{~m} /$ year (USACE 2007).

The primary anthropogenic sources of mercury in the region are coal-burning power plants (Crowe 1996; TDSHS 1999). Caddo Lake is located within $250 \mathrm{~km}$ of 5 of the 20 power plants with the highest mercury emissions in North America (Miller and Van Atten 2004). A fish consumption advisory has been issued for largemouth bass in Caddo Lake by the Texas Department of State Health Services (TDSHS 1995). The TDSHS recommends that consumption of largemouth bass be limited to two meals per month (serving size $=227 \mathrm{~g}$ for adults and $113 \mathrm{~g}$ for children). The Louisiana Department of Environmental Quality monitors largemouth bass on the Louisiana side of Caddo 


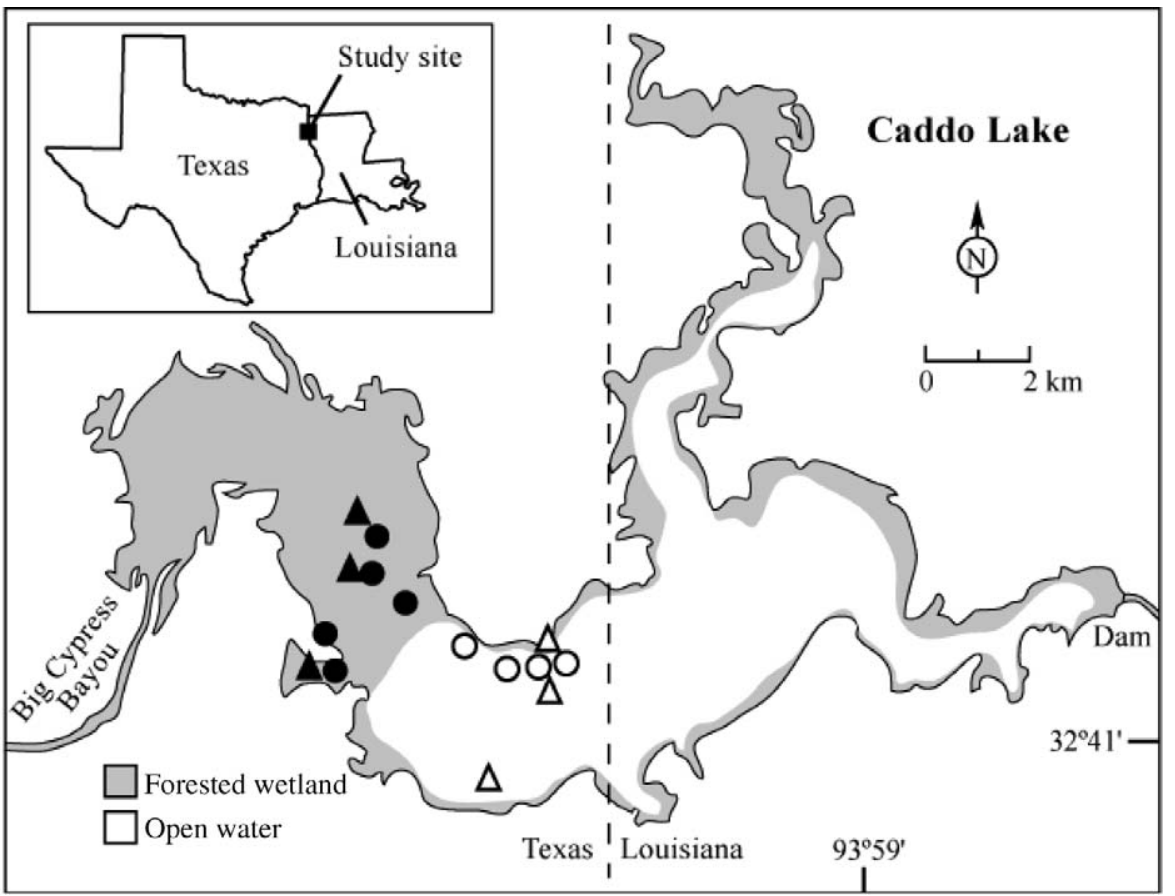

FIgURE 1.-Map of Caddo Lake, located on the border of Texas and Louisiana, where largemouth bass (circles) and Mississippi grass shrimp (triangles) were collected from forested wetland (black symbols) and open-water (open symbols) habitats to determine mercury concentrations. The $40-\mathrm{km}^{2}$ forested wetland in the western side of the lake has high densities of emergent and submerged aquatic vegetation; the eastern side is primarily open-water habitat.

Lake, but they have not issued an advisory (LDEQ 2005).

Fish and invertebrate collection.-We collected largemouth bass with assistance from biologists from the Texas Parks and Wildlife Department (TPWD) during the early evening of 10 May 2004 and the morning of 12 May 2004 using a boat-mounted electrofishing unit. Largemouth bass were collected from five sites in wetland habitat ( $n=44$ fish) and four sites in open-water habitat ( $n=47$ fish; Figure 1). After collection, fish were placed on ice and transported to a laboratory where total length (TL) was measured and sagittal otoliths were removed. Fish were then frozen for subsequent mercury and stable isotope analyses.

We assumed that largemouth bass were resident in the habitat from which they were collected. Based on a study of activity patterns of largemouth bass in a shallow (mean depth $=3.0 \mathrm{~m}$ ) reservoir in the southern United States, Sammons and Maceina (2005) concluded that largemouth bass in large systems are relatively sedentary and spend much of their time in small $(<5$ ha) areas despite an abundance of available habitat. Other studies have also suggested that largemouth bass home ranges are small (0.01-5.16 ha; Warden and Lorio 1975; Mesing and Wicker 1986).
To provide insight into mercury concentrations near the base of the food web, we collected Mississippi grass shrimp, a common macroinvertebrate in Caddo Lake. In their studies of Swedish lakes, Lindqvist et al. (1991) used mercury concentrations in short-lived consumers that fed near the base of the food web to identify differences in the availability of methylmercury between lakes. We examined mercury concentrations in Mississippi grass shrimp as indicators of mercury concentration near the base of the food web in the wetland and open-water habitats of Caddo Lake. The shrimp were collected with a dip net from vegetation floating on the surface of the water from three sites in wetland habitat ( $n=26$ shrimp) and three sites in open-water habitat ( $n=29$ shrimp) on 10 May 2006. They were placed on ice and transported to a laboratory, where they were identified to species and measured for TL under a dissecting microscope. The shrimp were then frozen for subsequent mercury analyses.

Stable isotope ratios of $\mathrm{N}$ and $\mathrm{C}$ in consumers like largemouth bass can be used to infer trophic relationships when interpreted relative to isotope ratios in primary consumers. Therefore, we collected gastropods and unionid mussels as representative primary con- 
sumers (Post et al. 2000). Gastropods and unionids were collected by hand or with a dip net from one site in wetland habitat (5 gastropods and 6 unionids) and one site in open-water habitat (1 gastropod and 5 unionids) on 18 May 2004. After collection, gastropods and unionids were frozen until processing for stable isotope analyses.

Mercury analysis. - Largemouth bass and Mississippi grass shrimp were processed separately for analyses of mercury concentration. Fillets of largemouth bass epaxial muscle were dissected from each fish, and a small subsample of skinless tissue was collected from the center of each fillet using a scalpel and forceps and weighed to the nearest $0.1 \mathrm{mg}$. Whole shrimp were dried at $60^{\circ} \mathrm{C}$ for $48 \mathrm{~h}$, homogenized with a ball mill grinder (Dentsply, Inc, York, Pennsylvania), and weighed to the nearest $0.1 \mathrm{mg}$. All laboratory equipment was rinsed with $50 \% \mathrm{HNO}_{3}$ solution (for largemouth bass) or $95 \%$ ethanol (for Mississippi grass shrimp) and deionized water between samples.

Total mercury concentrations in fish and shrimp tissue were analyzed with a direct mercury analyzer (Milestone, Inc., Monroe, Connecticut; DMA-80) that uses thermal decomposition, gold amalgamation, and atomic absorption spectrometry (USEPA 1998). Concentrations are reported as nanograms of total mercury per gram wet weight (WW) of fish or per gram dry weight (DW) of Mississippi grass shrimp tissue. We used total mercury as a proxy for methylmercury because (1) Bloom (1992) estimated that methylmercury accounted for $95 \%$ of the total mercury in several species of fish (including largemouth bass) and a marine shrimp, (2) the USEPA (2000) recommends analyzing total mercury in fish tissues as a proxy for methylmercury, and (3) Cleckner et al. (1998) found that methylmercury made up a high percentage of total mercury in grass shrimps Palaemonetes spp. and therefore used total mercury as a proxy for methylmercury.

For largemouth bass mercury analyses, a calibration curve was generated using three reference materials from the Institute for National Measurement Standards (National Research Council of Canada): MESS-3 (marine sediment, certified value $=91 \pm 9 \mathrm{ng}$ mercury/g DW (average $\pm 95 \%$ confidence interval $[\mathrm{CI}]$ ), PACS-2 (marine sediment, certified value = $3,040 \pm 200 \mathrm{ng}$ mercury/g DW), and DORM-2 (dogfish Squalus spp. muscle, certified value $=4,640$ $\pm 260 \mathrm{ng}$ mercury/g DW). Quality assurance included reference and duplicate samples. At approximately every 10th sample during largemouth bass mercury analyses, reference samples of MESS-3 or DORM-2 were analyzed and the mean percent recovery was 100 $\pm 1 \%($ range $=92-107 \%, n=41)$ and $100 \pm 2 \%$ (range $=95-104 \%, n=11)$, respectively. At approximately every 10th sample during Mississippi grass shrimp mercury analyses, reference samples of MESS3 were analyzed and the mean percent recovery was $98.8 \pm 0.6 \%$ (range $=98-100 \%, n=6$ ). Duplicate samples were analyzed at approximately every 20th sample, and the mean relative percent difference was $3.6 \pm 1.3 \%$ for largemouth bass (range $=0.3-11.4 \%, n$ $=28$ ) and $0.2 \pm 0.3 \%$ for Mississippi grass shrimp (range $=0.0-0.4 \%, n=3$ ). To compare Mississippi grass shrimp and largemouth bass mercury concentrations, we converted DW-based values for the shrimp to WW equivalents assuming a DW : WW ratio of 0.2:1.0 (Vernberg and Piyatiratitivorakul 1998).

Largemouth bass age and absolute growth rates.We examined otolith annuli to estimate the age of a subset of largemouth bass ( 33 from wetland habitat; 32 from open-water habitat). Otoliths were broken perpendicular to the longest axis through the nucleus and polished using 400- and 600-grit sandpaper (Buckmeier and Howells 2003). Annuli were counted at 8$40 \times$ magnification under a dissecting microscope with a fiber-optic light source. Two readers independently estimated the ages of fish without knowledge of fish $\mathrm{TL}$, and disagreements were resolved by reexamining otoliths and mutually agreeing on age. Absolute growth rates (hereafter, growth rates) were determined as TL divided by age.

Largemouth bass trophic position and diet.-Stable $\mathrm{N}$ and $\mathrm{C}$ isotope ratios in largemouth bass and primary consumers (unionids and gastropods) were used to examine differences in largemouth bass TPs and horizontal food web position across the two habitat types. Stable $\mathrm{N}$ isotopes are used differentially in cellular processes (Fry 2006), resulting in a predictable increase in the heavy isotope $\left({ }^{15} \mathrm{~N}\right)$ relative to ${ }^{14} \mathrm{~N}$ with each increase in vertical trophic level (Minagawa and Wada 1984). Horizontal food web position can be determined using stable $\mathrm{C}$ isotopes $\left({ }^{13} \mathrm{C}\right.$ and $\left.{ }^{12} \mathrm{C}\right)$ because benthic and pelagic primary producers have distinct $\mathrm{C}$ isotope signatures (Hecky and Hesslein 1995).

Largemouth bass fillet subsamples and foot muscle from gastropods and unionids were dried in a $60^{\circ} \mathrm{C}$ oven and homogenized using a ball mill grinder. Sixtyone largemouth bass ( 31 from wetland habitat; 30 from open-water habitat) were analyzed at Louisiana State University for isotopic composition using a Thermoquest Finnigan Delta Plus isotope ratio mass spectrometer (IRMS). The remaining fish (13 from wetland habitat; 17 from open-water habitat) and primary consumers were analyzed at the University of California-Davis stable isotope facility using a Europa Hydra 20/20 continuous-flow IRMS. Tank N and 
carbon dioxide gases calibrated with known standards were used as working reference materials in daily laboratory operation. Carbon and nitrogen isotope results are given as:

$$
\delta^{13} \mathrm{C} \text { or } \delta^{15} \mathrm{~N}=\left(R_{\text {sample }} / R_{\text {standard }}-1\right) \times 1,000,
$$

where $R={ }^{13} \mathrm{C} /{ }^{12} \mathrm{C}$ for $\delta^{13} \mathrm{C}$ or ${ }^{15} \mathrm{~N} /{ }^{14} \mathrm{~N}$ for $\delta^{15} \mathrm{~N}$. Standards for $\delta^{13} \mathrm{C}$ and $\delta^{15} \mathrm{~N}$ were Vienna Pee Dee Belemnite and air $\mathrm{N}_{2}$, respectively. Analysis of replicate samples of dried bovine liver (National Institute of Standards and Technology) indicated good agreement between the results from each laboratory (mean $\delta^{15} \mathrm{~N}$ and $\delta^{13} \mathrm{C}$ differed by $0.5 \%$ and $0.2 \%$, respectively).

To calculate TP, $\delta^{15} \mathrm{~N}$ values in largemouth bass were first corrected for habitat-specific differences in basal $\delta^{15} \mathrm{~N}$ using $\delta^{15} \mathrm{~N}$ and $\delta^{13} \mathrm{C}$ of primary consumers according to the method of Post (2002). Primary consumers that use littoral sources of $\mathrm{C}$ are less enriched in ${ }^{15} \mathrm{~N}$ than organisms that use pelagic sources of $\mathrm{C}$ (Post 2002), so we collected gastropods and unionids as representatives of littoral and pelagic primary consumers, respectively (Post et al. 2000; Post 2002). Thus, ${ }^{15} \mathrm{~N}$ values of largemouth bass $\left(\delta^{15} \mathrm{~N}_{\text {largemouth bass }}\right)$ collected from wetland and open-water habitats were corrected for differences in ${ }^{15} \mathrm{~N}$ at the base of the food web using gastropods $\left(\delta^{15} \mathrm{~N}_{\text {gastropod }}\right)$ and unionids $\left(\delta^{15} \mathrm{~N}_{\text {unionid }}\right)$ collected from the corresponding habitat. Corrected $\delta^{15} \mathrm{~N}\left(\delta^{15} \mathrm{~N}_{\text {corrected }}\right)$ values were calculated as:

$$
\begin{aligned}
& \delta^{15} \mathrm{~N}_{\text {corrected }}= \\
& \delta^{15} \mathrm{~N}_{\text {largemouth bass }}-( \\
& \quad \delta^{15} \mathrm{~N}_{\text {unionid }} \times \alpha \\
& \left.+\delta^{15} \mathrm{~N}_{\text {gastropod }} \times[1-\alpha]\right),
\end{aligned}
$$

where $\alpha$ is the proportion of $\mathrm{N}$ in largemouth bass that was ultimately derived from the pelagic food web; $\alpha$ was calculated as:

$$
\alpha=\frac{\delta^{13} \mathrm{C}_{\text {largemouth bass }}-\delta^{13} \mathrm{C}_{\text {gastropod }}}{\delta^{13} \mathrm{C}_{\text {unionid }}-\delta^{13} \mathrm{C}_{\text {gastropod }}},
$$

where $\delta^{13} \mathrm{C}$ values are those of largemouth bass, unionid mussels, and gastropods, as indicated. Gastropod $\delta^{15} \mathrm{~N}$ and $\delta^{13} \mathrm{C}$ (mean $\pm 95 \% \mathrm{CI}$ ) were $4.32 \pm 0.69 \%$ and $-29.4 \pm 1.16 \%$, respectively, for the wetland habitat and $2.23 \%$ and $-25.8 \%$, respectively, for the open-water habitat. Unionid $\delta^{15} \mathrm{~N}$ and $\delta^{13} \mathrm{C}$ were $6.50 \pm 0.66 \%$ and $-33.5 \pm 0.13 \%$, respectively, for wetland habitat and $4.85 \pm 0.22 \%$ and $-32.4 \pm 0.53 \%$, respectively, for open-water habitat. We used $\delta^{15} \mathrm{~N}_{\text {corrected }}$ values for largemouth bass to calculate TP as:

$$
\mathrm{TP}_{\text {largemouth bass }}=\delta^{15} \mathrm{~N}_{\text {corrected }} / 3.4+2 .
$$

We corrected $\delta^{13} \mathrm{C}_{\text {largemouth bass }}$ for trophic enrichment according to the method of Fry (2006) as:

$$
\begin{aligned}
\delta^{13} \mathrm{C}_{\text {corrected }}= & \delta^{13} \mathrm{C}_{\text {largemouth bass }} \\
& -0.5 \times\left(\mathrm{TP}_{\text {largemouth bass }}-1\right) .
\end{aligned}
$$

Corrected $\delta^{13} \mathrm{C}_{\text {largemouth bass }}$ values were compared with $\delta^{13} \mathrm{C}$ of gastropods and unionids to determine whether largemouth bass were feeding predominately in either pelagic or littoral food webs.

Statistical analyses. - We used a series of analysis of covariance (ANCOVA) models in the Statistical Package for the Social Sciences (SPSS; version 11.5.0; SPSS, Inc., Chicago, Illinois) to test for differences in largemouth bass characteristics between habitats. Specifically, we compared largemouth bass mercury concentrations (dependent variable) between habitats (categorical variable) with fish TL and age included as covariates (continuous variables). We tested for differences in largemouth bass growth rates by comparing TL between habitats with age included as the covariate. Finally, largemouth bass TP and $\delta^{13} \mathrm{C}$ (i.e., horizontal food web position) were compared between habitats and TL was included as the covariate. For the preceding ANCOVA models, when the slopes of the relationships between the covariate and dependent variable were homogeneous between habitats (i.e., habitat $\times$ covariate $P>0.05$ ), we removed the interaction term from the model and tested for main effects of habitat and the covariate. If the slopes of the covariate and the dependent variable were not homogenous, we tested for main effects of habitat and the covariate with the interaction term included in the model and we performed the Wilcox procedure (Quinn and Keough 2002). This test determines the range of the covariate for which there was a significant habitat effect (WILCOX version 3.2; Constable 1989). We also used a general linear model (GLM) in SPSS to test the predictive power of multiple explanatory variables on largemouth bass mercury concentration and to determine whether there was a unique effect of habitat on fish mercury concentration after including multiple explanatory variables in the model. Specifically, we tested for differences in $\log _{10}$ (mercury concentration) of largemouth bass between the two habitat types (categorical variable); several covariates (TP, $\delta^{13} \mathrm{C}$, TL, and growth rate) and all habitat $\times$ covariate interaction terms were included in the model. We also tested for differences in $\log _{10}$ (mercury concentration) of largemouth bass between the two habitat types after removing all habitat $\times$ covariate interaction terms from the model. Finally, we tested for habitat-specific differences in mercury concentration and TL of Mississippi grass shrimp by use of 
TABLE 1.-Mean $( \pm 95 \%$ CI $)$ characteristics of largemouth bass collected ( $n=$ number sampled) from forested wetland and open-water habitats in Caddo Lake, Texas-Louisiana, during May 2004.

\begin{tabular}{lcr}
\hline \multicolumn{1}{c}{ Variable } & $\begin{array}{c}\text { Forested wetland } \\
(n=44)\end{array}$ & $\begin{array}{c}\text { Open water } \\
(n=47)\end{array}$ \\
\hline $\begin{array}{l}\text { Mercury concentration } \\
\text { (ng/g wet weight) }\end{array}$ & $465 \pm 113$ & $193 \pm 54$ \\
Total length (mm) & $287 \pm 37$ & $260 \pm 33$ \\
Age (years) & $3.9 \pm 0.7$ & $2.6 \pm 0.5$ \\
Growth rate (mm/year) $^{\mathrm{a}}$ & $101 \pm 11$ & $138 \pm 13$ \\
Trophic position $^{13} \mathrm{C}(\%)$ & $4.1 \pm 0.1$ & $4.2 \pm 0.1$ \\
& $-29.6 \pm 0.3$ & $-30.0 \pm 0.3$ \\
\hline
\end{tabular}

${ }^{a}$ Age and growth rate were determined for 33 fish from forested wetland and 32 fish from open-water habitat.

independent-sample $t$-tests in SPSS. The significance level was 0.05 for all analyses.

We checked our data for linearity, normality, and homogeneity of variance using scatter and residual plots (Quinn and Keough 2002), and some data were transformed to meet model assumptions. Specifically, mercury (dependent variable) was $\log _{10}$ transformed in the model that included TL as a covariate and the model that included $\mathrm{TP}, \delta^{13} \mathrm{C}$, TL, and growth rate as covariates. Covariates TL and age were $\log _{e}$ transformed in the models that included $\delta^{13} \mathrm{C}$ and $\mathrm{TL}$ as dependent variables, respectively. Although some data were linearized for statistical analyses, untransformed data are presented in all figures to facilitate interpretation.

\section{Results}

Mercury concentrations were 2.4 times higher in largemouth bass from wetland habitat than in those from open-water habitat (Table 1). Largemouth bass from wetland habitat were of similar size, but 1.5 times older than the fish from open-water habitat (Table 1). After controlling for the effects of TL or age, we found that largemouth bass collected from wetland habitat still had significantly higher concentrations of mercury than those collected from open-water habitat (Table 2; Figure 2).
Mean growth rate was 1.4 times lower in largemouth bass from wetland habitat than in those from openwater habitat (Table 1); wetland largemouth bass were significantly smaller than open-water fish of similar age (Table 2; Figure 3). The mean TP of largemouth bass was not different between habitats (Table 1); however, after controlling for the effect of TL, we determined that largemouth bass from wetland habitat had significantly lower TPs than those from open-water habitat (Table 2; Figure 4A).

Mean horizontal food web position $\left(\delta^{13} \mathrm{C}\right)$ in largemouth bass was similar between habitats (Table 1) but was dependent on TL (Table 2; Figure 4B). Small largemouth bass $(<244 \mathrm{~mm})$ collected from wetland habitat were significantly more enriched in ${ }^{13} \mathrm{C}$ than those from open-water habitat. Comparison of largemouth bass $\delta^{13} \mathrm{C}$ values with $\delta^{13} \mathrm{C}$ values of primary consumers indicated that small largemouth bass from wetlands were feeding in food webs based on littoral primary production (i.e., $\delta^{13} \mathrm{C}$ values were similar to those in gastropods), whereas small largemouth bass in open-water habitat were feeding in food webs based on pelagic primary production (i.e., $\delta^{13} \mathrm{C}$ values were similar to those in unionids). The $\delta^{13} \mathrm{C}$ values for medium-sized largemouth bass (244-370 $\mathrm{mm}$ ) were not significantly different between habitats and were intermediate between the $\delta^{13} \mathrm{C}$ values of unionids and gastropods. Large largemouth bass $(>370$ $\mathrm{mm}$ ) collected from wetland habitat were significantly less enriched in ${ }^{13} \mathrm{C}$ than those collected from openwater habitat after adjustment for TL effects (Table 2). These data indicate that large largemouth bass $(>370$ $\mathrm{mm})$ from wetland habitat were more dependent on pelagic food webs than similar-sized fish from openwater habitat; however, $\delta^{13} \mathrm{C}$ values for largemouth bass from both habitats were intermediate between the $\delta^{13} \mathrm{C}$ values of unionids and gastropods.

To predict mercury concentration in largemouth bass, we used a GLM that included largemouth bass $\mathrm{TP}, \delta^{13} \mathrm{C}$, TL, growth rate, habitat, and all covariate $\times$

TABLE 2.-Analysis of covariance and Wilcox procedure significance values used to examine the effect of habitat type (forested wetland or open water) on mercury concentration, trophic position, stable isotope ratio $\left(\delta^{13} \mathrm{C}\right)$, and total length (TL) of largemouth bass in Caddo Lake, Texas-Louisiana, May 2004.

\begin{tabular}{|c|c|c|c|c|c|c|c|c|c|c|c|}
\hline \multirow[b]{3}{*}{ Dependent variable } & \multirow[b]{3}{*}{ Covariate } & & & & \multicolumn{6}{|c|}{ ANCOVA } & \multirow{3}{*}{$\begin{array}{c}\text { Wilcox } \\
\text { significance range }\end{array}$} \\
\hline & & \multicolumn{3}{|c|}{ Covariate $\times$ Habitat } & \multicolumn{3}{|c|}{ Habitat } & \multicolumn{3}{|c|}{ Covariate } & \\
\hline & & df & $F$ & $P$ & $\mathrm{df}$ & $F$ & $P$ & $\mathrm{df}$ & $F$ & $P$ & \\
\hline $\log _{10}$ (mercury concentration) & $\mathrm{TL}$ & 1,87 & 2.7 & 0.1 & 1,88 & 87.6 & $<0.001$ & 1,88 & 309 & $<0.001$ & - \\
\hline Mercury & Age & 1,61 & 2.2 & 0.1 & 1,62 & 17.5 & $<0.001$ & 1,62 & 241 & $<0.001$ & - \\
\hline Trophic position & TL & 1,87 & 0.03 & 0.9 & 1,88 & 13.1 & $<0.001$ & 1,88 & 67.1 & $<0.001$ & - \\
\hline$\delta^{13} \mathrm{C}$ & $\log _{e}(\mathrm{TL})$ & 1,87 & 34.8 & $<0.001$ & 1,87 & 36.7 & $<0.001$ & 1,87 & 0.55 & 0.46 & $<244$ to $>370 \mathrm{~mm}$ \\
\hline TL & $\log _{e}$ (age) & 1,61 & 0.24 & 0.6 & 1,62 & 20.3 & $<0.001$ & 1,62 & 439 & $<0.001$ & - \\
\hline
\end{tabular}




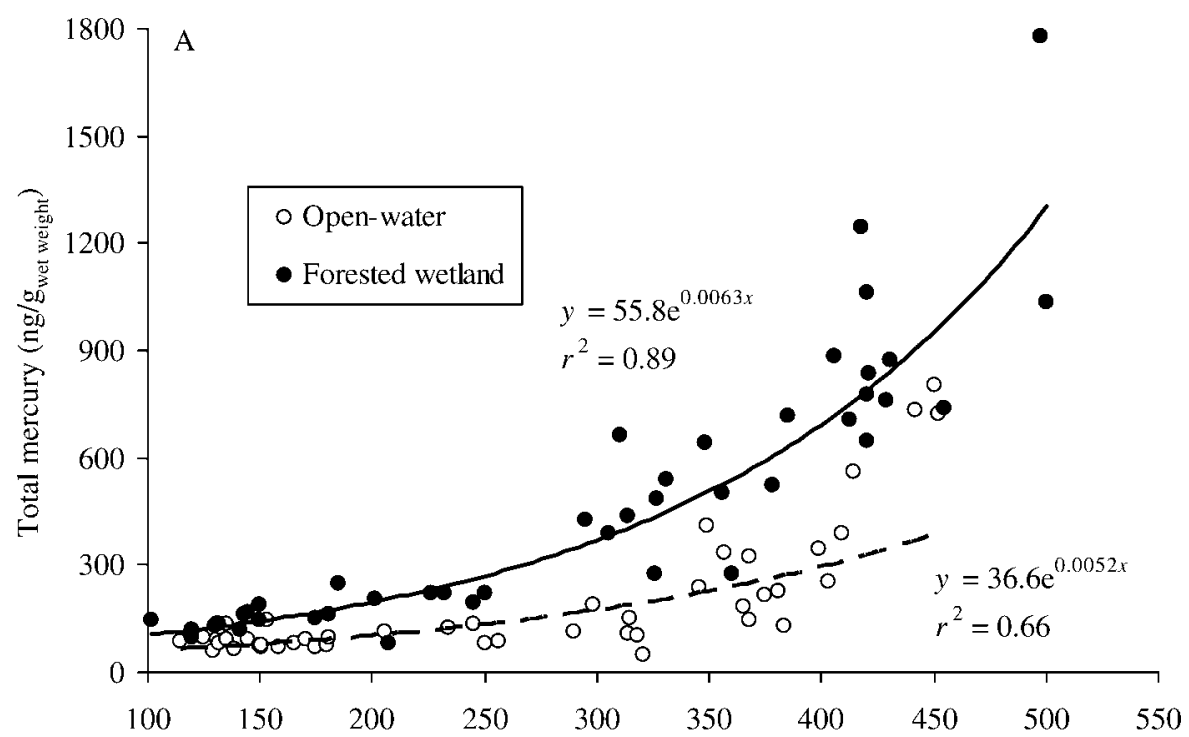

Total length $(\mathrm{mm})$

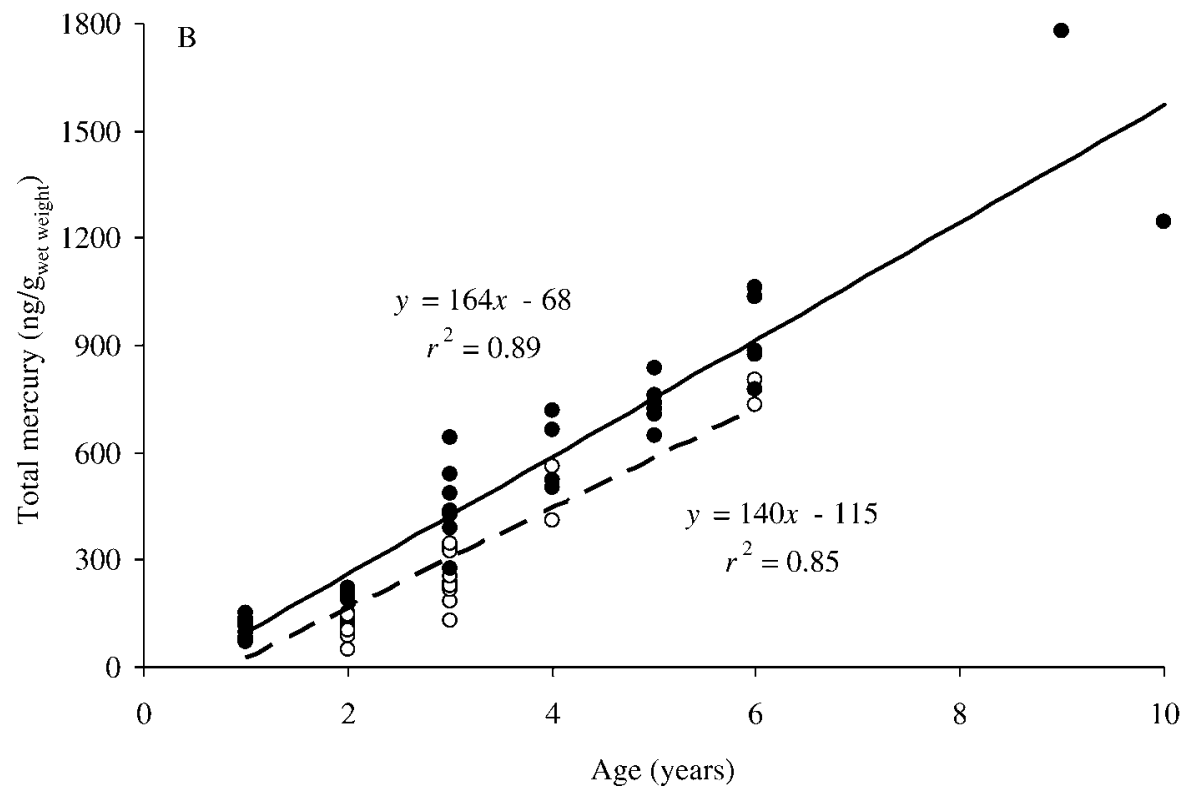

FIGURE 2.- Relationship between largemouth bass (A) TL or (B) age and total mercury concentration in epaxial muscle (ng mercury/g wet weight) from fish collected in forested wetland and open-water habitats of Caddo Lake, Texas-Louisiana, during May 2004.

habitat interactions. These variables explained most of the variation in $\log _{10}$ (mercury concentration) (GLM: $\mathrm{df}$ $\left.=9,55 ; F=66.6 ; P<0.001 ; R^{2}=0.92\right)$. All variables except $\delta^{13} \mathrm{C}(\mathrm{df}=1,55 ; F=3.29 ; P=0.08$; partial regression coefficient $\eta^{2}=0.06$ ), the growth rate $\times$ habitat interaction $\left(\mathrm{df}=1,55 ; F=1.40 ; P=0.24 ; \eta^{2}=\right.$ $0.03)$, and the $\mathrm{TL} \times$ habitat interaction $(\mathrm{df}=1,55 ; F=$ $\left.0.29 ; P=0.59 ; \eta^{2}=0.01\right)$ were significantly related to largemouth bass $\log _{10}$ (mercury concentration). Even when all covariates and covariate $\times$ habitat interactions were included in the model, habitat explained $21 \%$ of the variation in mercury concentration; largemouth bass from wetland habitat had higher mercury concentrations than those from open-water habitat 


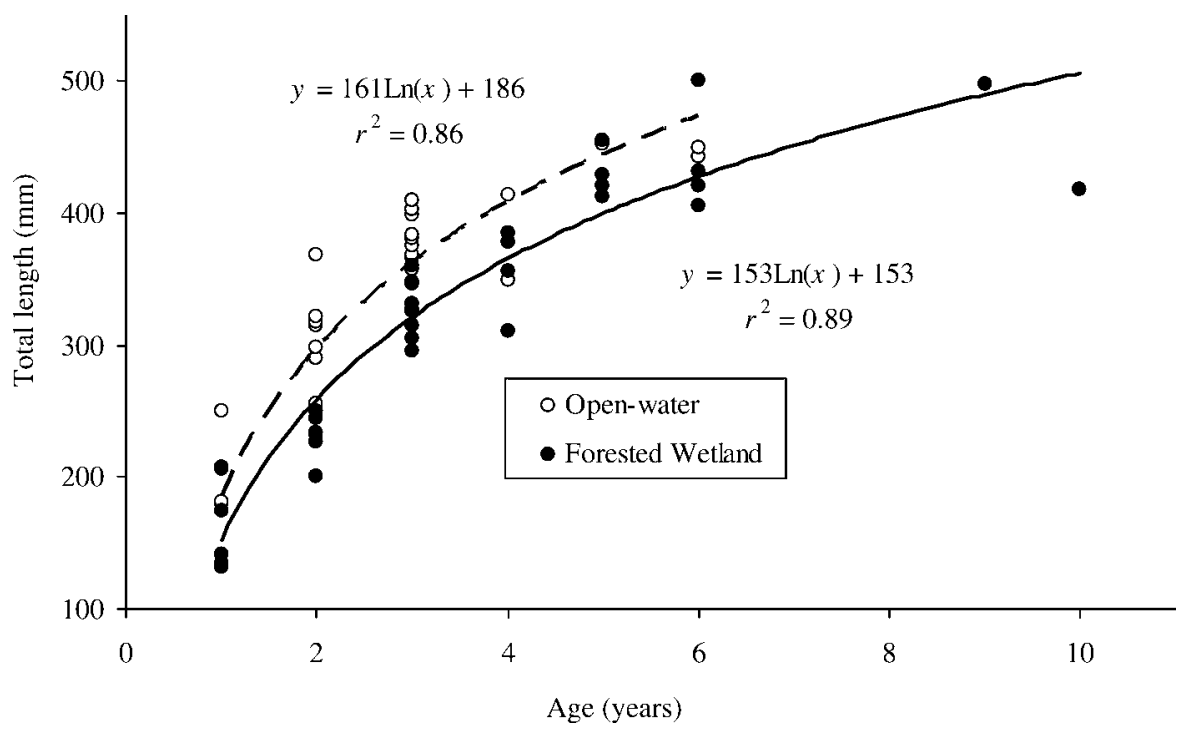

FIGURE 3.- Relationship between TL and age of largemouth bass collected from forested wetland and open-water habitats of Caddo Lake, Texas-Louisiana, during May 2004.

(GLM: df $\left.=1,55 ; F=14.5 ; P<0.001 ; \eta^{2}=0.21\right)$. After removing all habitat $\times$ covariate interactions from the model, we found that largemouth bass TP, $\delta^{13} \mathrm{C}$, $\mathrm{TL}$, growth rate, and habitat explained a large proportion of the variation in $\log _{10}$ (mercury concentration) $\left(\mathrm{df}=5,59 ; F=96.9 ; P<0.001 ; R^{2}=0.89\right)$. All variables except $\delta^{13} \mathrm{C}(\mathrm{df}=1,59 ; F=0.54 ; P=$ $\left.0.47 ; \eta^{2}=0.01\right)$ were significantly related to largemouth bass $\log _{10}$ (mercury concentration). Habitat explained $37 \%$ of the variation in mercury concentration: largemouth bass from wetland habitat had higher concentrations than those from open-water habitat $(\mathrm{df}=$ 1,$\left.59 ; F=34.2 ; P<0.001 ; \eta^{2}=0.37\right)$. These results indicate that largemouth bass TP, $\delta^{13} \mathrm{C}$, TL, and growth rate are not sufficient to explain the habitat-specific differences in mercury concentration observed in this study and that habitat explains a unique proportion of the variance in largemouth bass mercury concentration.

Mississippi grass shrimp from wetland habitat $(\mathrm{TL}=$ $29.0 \pm 0.9 \mathrm{~mm}$ ) were significantly smaller than those from open-water habitat $(\mathrm{TL}=31.2 \pm 1.5 \mathrm{~mm}$; $t$-test: $\mathrm{df}=53, t=2.51, P=0.02)$. Shrimp from wetland habitat had significantly higher mercury concentrations than those from open-water habitat $(t$-test: $\mathrm{df}=53, t=$ -3.02, $P=0.004)$. Shrimp collected from wetland habitat had a mean mercury concentration of $69.5 \pm$ $6.2 \mathrm{ng} / \mathrm{g}$ DW (corrected), whereas shrimp collected from open-water habitat had a mercury concentration of $57.4 \pm 5.0 \mathrm{ng} / \mathrm{g} \mathrm{DW}$ (corrected).

\section{Discussion}

Spatial and habitat variability in fish mercury concentration has been observed in lakes and reservoirs located in temperate and tropical regions (Munn and Short 1997; Cizdziel et al. 2002; Campbell et al. 2003a; Burger et al. 2004; Stafford et al. 2004; Simoneau et al. 2005). In this study, we made the novel observation that largemouth bass collected from wetland habitat were more than twice as contaminated with mercury as those from open-water habitat. Largemouth bass mercury concentrations were higher in the wetland habitat as a function of both TL and age. There are two possible mechanisms to explain the greater mercury contamination of largemouth bass in wetland habitat: (1) differences in growth rate and (2) differences in the mercury concentration of diets.

Results of a modeling study by Rodgers (1996) provide a means to discriminate between the effects of growth rate and diet on mercury concentration in fish. Rodgers (1996) used bioenergetics-based equations of contaminant accumulation with a fish bioenergeticsbased model to predict mercury accumulation in reservoir fish. Rodgers' (1996) study showed that differences in growth rate or dietary mercury concentration can produce length-specific differences in mercury similar to the pattern found in this study (Figure 2A). Specifically, the higher length-specific concentrations of mercury observed in wetland fish could have been caused either by their slow growth rates or by a diet that was more contaminated with 

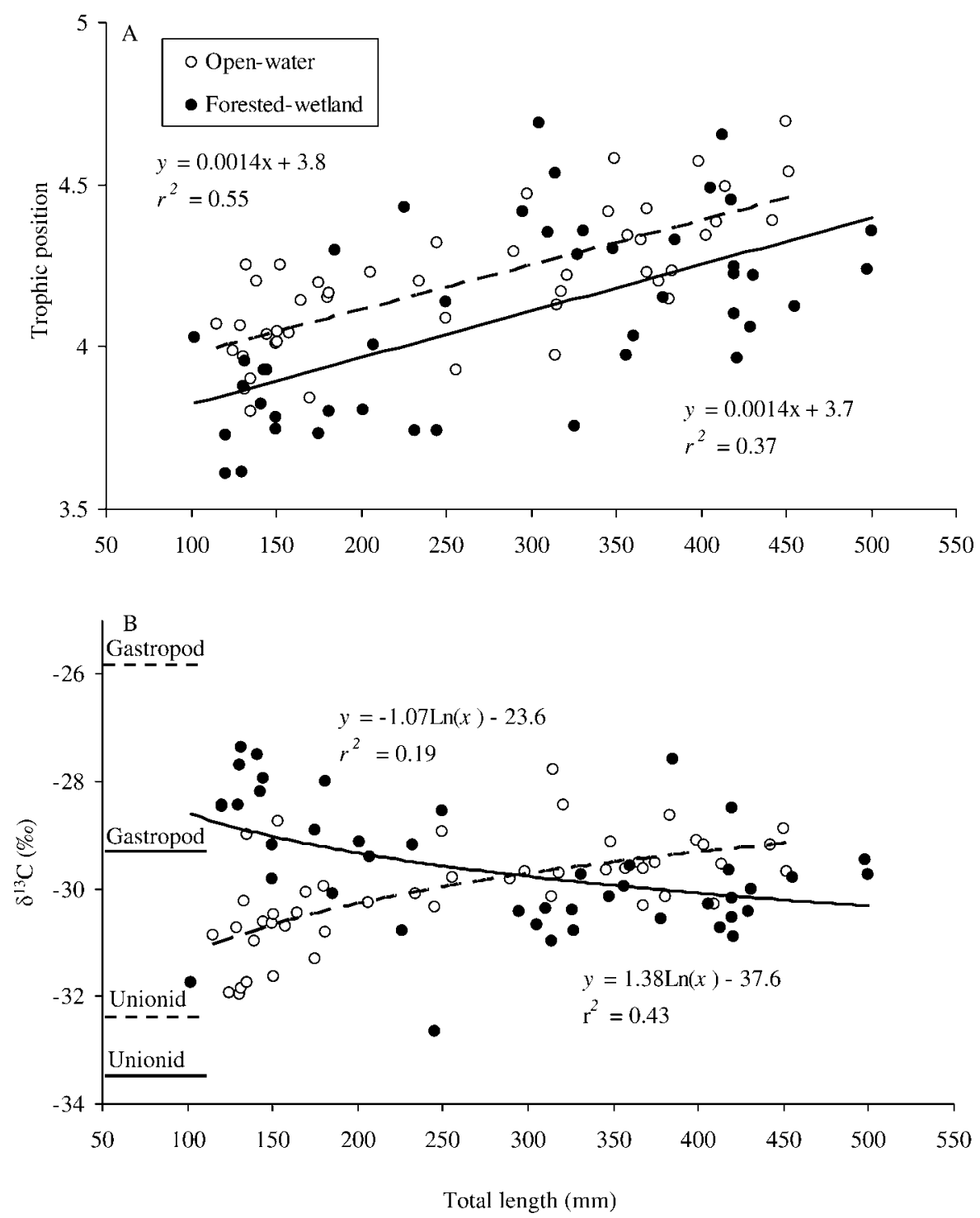

FIGURE 4.- Relationship between largemouth bass (A) trophic position or (B) $\delta^{13} \mathrm{C}$ and TL from fish collected in forested wetland and open-water habitats of Caddo Lake, Texas-Louisiana, during May 2004. Gastropod and unionid $\delta^{13} \mathrm{C}$ values (horizontal solid lines $=$ forested wetland; horizontal dashed lines $=$ open water) are also provided.

mercury. Rodgers (1996) also modeled the effects of growth rate and diet on age-specific mercury concentrations in fish. When he modeled the effect of growth rate on age-specific mercury concentration, he found that slow-growing fish had lower concentrations for a given age, a pattern that is inconsistent with our results (Figure 2B). When Rodgers (1996) modeled the effect of diet on age-specific mercury concentration, he found that fish that consumed high dietary mercury concen- trations had higher concentrations for a given age; this pattern is consistent with our results (Figure 2B). Because age-specific mercury concentrations observed in our study are similar to those Rodgers (1996) would predict based on dietary mercury differences between habitats, we conclude that increased mercury concentrations in largemouth bass from the wetland habitat are attributable to differences in diet rather than differences in growth rate. 
Elevated mercury concentrations in the diets of largemouth bass from wetland habitat could be caused by three mechanisms: (1) these fish were feeding at a higher TP, (2) these fish were feeding within a more pelagic-based food web, and (3) their entire food web was more contaminated with mercury than the food web in the open-water habitat.

We did not find support for mechanism (1); thus, we conclude that variation in mercury concentration was not caused by habitat-specific differences in largemouth bass TP. Fish feeding at higher TPs often have elevated mercury concentrations due to biomagnification (Cabana and Rasmussen 1994). Largemouth bass from the wetland habitat had lower TP than those from the open-water habitat. Even though TPs were lower, the mercury concentrations of fish from wetland habitat were significantly higher than in fish from open-water habitat, which indicates that some other factor overrode the effect of TP on fish mercury concentration.

We did not find support for mechanism (2), and we conclude that variation in mercury concentration was not caused by habitat-specific differences in horizontal food web position. Fish feeding in food webs based predominantly on pelagic primary production often have elevated concentrations of mercury (Lindqvist et al. 1991; Power et al. 2002; Gorski et al. 2003; Kidd et al. 2003). Despite being dependent on food webs based on pelagic primary production, small largemouth bass collected from open-water habitat within Caddo Lake had lower mercury concentrations than similar-sized individuals from wetland habitat. For small largemouth bass, the patterns exhibited by $\mathrm{C}$ isotopes were opposite those that would be expected if differences in reliance on pelagic primary production were driving habitat-specific differences in mercury concentration (Power et al. 2002). It is worth noting that the hypothesized inverse relationship between $\delta^{13} \mathrm{C}$ value and mercury in fish has only been reported in deep lakes with extensive pelagic zones (Power et al. 2002; Gorski et al. 2003; Kidd et al. 2003). However, in shallow ecosystems, littoral zones are important sites of mercury methylation (Cleckner et al. 1999). Therefore, the relationship between $\delta^{13} \mathrm{C}$ and mercury in fish may be ecosystem specific. Regardless of the relationship between $\delta^{13} \mathrm{C}$ and mercury, the pattern of $\delta^{13} \mathrm{C}$ values exhibited by medium- and large-sized largemouth bass indicate that some other factor was responsible for habitat-specific differences in mercury concentration. Medium and large fish exhibited the greatest difference in mercury concentration and the most similar $\delta^{13} \mathrm{C}$ values between habitats. Thus, differences in reliance on pelagic primary production between the two habitats were probably not responsible for the observed differences in mercury concentration in largemouth bass.

We tested mechanism (3) that the food web in the wetland habitat was more contaminated with mercury than the food web in the open-water habitat by examining mercury concentration in Mississippi grass shrimp as a proxy for mercury contamination at the base of the food web. Mercury concentration in Mississippi grass shrimp from wetland habitat was significantly higher than that in shrimp from openwater habitat. The higher concentrations in shrimp collected from wetland habitat provide evidence that mercury concentrations in organisms at the base of the food web differed between habitats and that methylmercury availability differed between habitats (Lindqvist et al. 1991). In addition, our GLM-based model of mercury concentration in largemouth bass indicated that habitat explained a relatively large amount of variation in mercury concentrations of individual fish, even when all covariates $\left(\mathrm{TP}, \delta^{13} \mathrm{C}\right.$, TL, and growth rate) were included in the model. We therefore conclude that the higher concentration of mercury in largemouth bass from wetland habitat was due to elevated mercury concentrations in the wetland food web.

All wetland types, including forested wetlands, have features that may make them conducive to mercury methylation (Zillioux et al. 1993; Ullrich et al. 2001; Wiener et al. 2003). Although mercury cycling in wetlands is not completely understood, there are probably several interacting factors that enhance mercury methylation and bioavailability in these ecosystems (Driscoll et al. 2007). High organic C concentrations in wetland sediments stimulate microbial activity and lead to anoxic conditions, which are ideal for anaerobic $\mathrm{SO}_{4}^{-2}$-reducing bacteria, the primary biological methylators of mercury (Ullrich et al. 2001; Munthe et al. 2007). Relative to open-water habitat, wetland habitat in Caddo Lake has high organic C concentrations in sediments (Wilson 2003) and low dissolved oxygen concentrations (Hartung 1983; Darville et al. 1998). Because mercury methylation is dependent on the activity of $\mathrm{SO}_{4}^{-2}$-reducing bacteria, mercury methylation may be limited by low $\mathrm{SO}_{4}^{-2}$ concentrations. However, high $\mathrm{SO}_{4}^{-2}$ can also limit methylation by forming complexes with mercury that reduce mercury bioavailability (Ullrich et al. 2001). Therefore, an $\mathrm{SO}_{4}^{-2}$ range of $0.2-0.5 \mathrm{mM}$ has been identified as the optimal concentration for mercury methylation (Ullrich et al. 2001). In contrast to open-water habitat, wetland habitat in Caddo Lake has $\mathrm{SO}_{4}^{-2}$ concentrations that are optimal for mercury methylation (i.e., between 0.2 and $0.5 \mathrm{mM} \mathrm{SO}_{4}^{-2}$; Hartung 1983). In addition to $\mathrm{SO}_{4}^{-2}$, low $\mathrm{pH}$ conditions 
common in many wetlands (Mitsch and Gosselink 2000) enhance the bioavailability of mercury, and low $\mathrm{pH}$ is consistently identified as a predictor of ecosystems with elevated methylmercury concentrations (Ullrich et al. 2001; Burgess 2005). Wetland habitat in Caddo Lake has lower pH (Hartung 1983; Darville et al. 1998) than open-water habitat. Finally, wetlands often experience water level fluctuations. Oxidation and reduction of soils associated with drying and rewetting leads to increased availability of $\mathrm{SO}_{4}^{-2}$ and inundation of organic matter, both of which stimulate microbial activity and methylation (Sorensen et al. 2005). In contrast to open-water habitat, wetland habitat in Caddo Lake is directly connected to seasonally flooded areas (Van Kley and Hine 1998).

In general, wetlands are sources of methylmercury in lakes and rivers (St. Louis et al. 1994; Hurley et al. 1995; Lee et al. 1998; Paller et al. 2004; Warner et al. 2005). However, the impact of methylmercury production in wetlands on mercury contamination in aquatic organisms has not been well studied (Wiener et al. 2003). Fish from lakes and reservoirs that contain wetlands within their watersheds have elevated concentrations of mercury (Greenfield et al. 2001; Warner et al. 2005), and rivers that drain wetlands contain invertebrates with elevated concentrations of mercury (Paller et al. 2004). Based on our results and those of previous studies, we hypothesize that biota in lakes or reservoirs with connections to wetlands will exhibit spatial variation in mercury contamination wherein organisms living in or near wetlands will exhibit elevated mercury concentrations.

Forested wetlands may be more at risk for containing organisms with elevated mercury concentrations than has been appreciated. There are more than $210,000 \mathrm{~km}^{2}$ of forested wetlands in the conterminous United States (Dahl 2006). Because mercury-contaminated fish have negative health effects on humans and wildlife, forested wetlands should be of special concern to public and environmental health officials, especially in the southern United States, where these habitats are extensive (Conner and Buford 1998) and where atmospheric deposition of mercury is elevated (NADP 2005).

The diversity of ecosystems in which spatial variation in mercury contamination of organisms has been reported (Munn and Short 1997; Cizdziel et al. 2002; Campbell et al. 2003a; Burger et al. 2004; Stafford et al. 2004; Simoneau et al. 2005) and the habitat-specific difference in mercury concentration observed in this study indicate that spatial variation in mercury contamination may be common and may confound efforts to assess bioaccumulation in fish. Thus, spatial variation in fish mercury concentration should be of concern to scientific researchers and environmental health officials responsible for monitoring contaminants in fish.

\section{Acknowledgments}

We are grateful to Mike Ryan, Michael Brice, and Jacob Green of the TPWD for their help in collecting fish. Sam and Randie Canup and Dale Reckenberger provided invaluable logistical support. Bill McClain, Jaron Hill, Mandy Davis, Keri McNew, and Kristin Appling provided assistance in the field and laboratory. John Pinder, Ingo Schlup, and David Cross provided statistical advice. Gary Wellborn provided laboratory space. Rickey Cothran, Jeff Kelley, Bob Nairn, Bill Shelton, and two anonymous reviewers provided helpful comments. Jean Evins drew Figure 1. Support for M.M.C. was provided by a University of Oklahoma (OU) Department of Zoology Adam's Fellowship and grants from the Texas Academy of Science, OU Graduate Student Senate, and OU Graduate College (Robberson Research Grant). Additional support was provided through a Texas Christian University Research Fund Grant to R.W.D and OU College of Arts and Sciences and Research Council awards to K.D.H. This work was submitted by M.M.C. in partial fulfillment of the Ph.D. degree at OU.

\section{References}

Bloom, N. S. 1992. On the chemical form of mercury in edible fish and marine invertebrate tissue. Canadian Journal of Fisheries and Aquatic Sciences 49:1010-1017.

Buckmeier, D. L., and R. G. Howells. 2003. Validation of otoliths for estimating ages of largemouth bass to 16 years. North American Journal of Fisheries Management 23:590-593.

Burger, J., E. F. Orlando, M. Gochfeld, G. A. Binczik, and L. J. Guillette, Jr. 2004. Metal levels in tissues of Florida gar (Lepisosteus platyrhincus) from Lake Okeechobee. Environmental Monitoring and Assessment 90:187-201.

Burgess, N. M. 2005. Mercury in biota and its effects. Pages 235-258 in M. B. Parsons and J. B. Percival, editors. Mercury: sources, measurements, cycles, and effects. Short course series, volume 34. Mineralogical Association of Canada, Halifax, Nova Scotia.

Cabana, G., and J. B. Rasmussen. 1994. Modeling food chain structure and contaminant bioaccumulation using stable nitrogen isotopes. Nature (London) 372:255-257.

Campbell, L. M., R. E. Hecky, J. Nyaundi, R. Muggide, and D. G. Dixon. 2003a. Distribution and food-web transfer of mercury in Napoleon and Winam gulfs, Lake Victoria, East Africa. Journal of Great Lakes Research 29:267282.

Campbell, L. M., R. E. Hecky, and S. B. Wandera. 2003b. Stable isotope analyses of food web structure and fish diet in Napoleon and Winam gulfs, Lake Victoria, East Africa. Journal of Great Lakes Research 29:243-257.

Cizdziel, J. V., T. A. Hinners, J. E. Pollard, E. M. Heithmar, 
and C. L. Cross. 2002. Mercury concentrations in fish from Lake Mead, USA, related to fish size, condition, trophic level, location, and consumption risk. Archives of Environmental Contamination and Toxicology 43:309317.

Clarkson, T. W. 2002. The three modern faces of mercury. Environmental Health Perspectives 110:11-23.

Cleckner, L. B., P. J. Garrison, J. P. Hurley, M. L. Olson, and D. P. Krabbenhoft. 1998. Trophic transfer of methyl mercury in the northern Florida Everglades. Biogeochemistry 40:347-361.

Cleckner, L. B., C. C. Gilmour, J. P. Hurley, and D. P. Krabbenhoft. 1999. Mercury methylation in periphyton of the Florida Everglades. Limnology and Oceanography 44:1815-1825.

Conner, W. H., and M. A. Buford. 1998. Southern deepwater swamps. Pages 261-287 in M. G. Messina and W. H. Conner, editors. Southern forested wetlands ecology and management. Lewis Publishers, Boca Raton, Florida.

Constable, A. 1989. WILCOX version 3.2. Available: www. zoology.unimelb.edu.au/qkstats/software.html. (September 2006).

Cowardin, L. M., V. Carter, F. C. Golet, and E. T. LaRoe. 1979. Classification of wetlands and deepwater habitats of the United States. U.S. Fish and Wildlife Service, Washington, D.C. Available: www.npwrc.usgs.gov/ resource/1998/classwet/classwet.htm. (October 2006).

Crowe, A. L. 1996. A survey of mercury concentrations in the Cypress Creek and upper Sabine River basins of northeast Texas. Texas Natural Resources Conservation Commission, Report AS-121/SR, Austin.

Dahl, T. E. 2006. Status and trends of wetlands in the conterminous United States 1998 to 2004. U.S. Fish and Wildlife Service, Washington, D.C.

Darville, R., D. K. Shellman, Jr., and R. Darville. 1998. Intensive water quality monitoring at Caddo Lake, a Ramsar wetland in Texas and Louisiana, USA. Caddo Lake Institute, Jefferson, Texas. Available: www.clidata. org/Reports/NewReports/clp00020.pdf. (September 2006).

Driscoll, C. T., Y. Han, C. Y. Chen, D. C. Evers, K. Fallon Lambert, T. M. Holsen, N. C. Kamman, and R. K. Munson. 2007. Mercury contamination in forest and freshwater ecosystems in the northeastern United States. BioScience 57:17-28.

Ensminger, P. A. 1999. Bathymetric survey and physical and chemical-related properties of Caddo Lake, Louisiana and Texas, August and September 1998. U.S. Geological Survey, Water Resources Investigations Report 99-4217, Denver.

Fry, B. 2006. Stable isotope ecology. Springer Science Business Media, New York.

Gorski, P. R., L. B. Cleckner, J. P. Hurley, M. E. Sierszen, and D. E. Armstrong. 2003. Factors affecting enhanced mercury bioaccumulation in inland lakes of Isle Royale National Park, USA. Science of the Total Environment 304:327-348.

Greenfield, B. K., T. R. Hrabik, C. J. Harvey, and S. R. Carpenter. 2001. Predicting mercury levels in yellow perch: use of water chemistry, trophic ecology, and spatial traits. Canadian Journal of Fisheries and Aquatic Sciences 58:1419-1429.
Hall, B. D., R. A. Bodaly, R. J. P. Fudge, J. W. M. Rudd, and D. M. Rosenberg. 1997. Food as the dominant pathway of methylmercury uptake by fish. Water, Air, and Soil Pollution 100:13-24.

Hartung, A.A. 1983. Physiochemical limnology of Caddo Lake, Texas and Louisiana. Master's thesis. Stephen F. Austin State University, Nacogdoches, Texas.

Hecky, R. E., and R. H. Hesslein. 1995. Contributions of benthic algae to lake food webs as revealed by stable isotope analysis. Journal of the North American Benthological Society 14:631-653.

Hurley, J. P., J. M. Benoit, C. L. Babiarz, M. M. Shafer, A. W. Andren, J. R. Sullivan, R. Hammond, and D. A. Webb. 1995. Influences of watershed characteristics on mercury levels in Wisconsin rivers. Environmental Science and Technology 29:1867-1875.

Johnels, A. G., T. Westermark, W. Berg, P. I. Persson, and B. Sjostrand. 1967. Pike (Esox lucius L.) and some other aquatic organisms in Sweden as indicators of mercury contamination in the environment. Oikos 18:323-333.

Kidd, K. A., H. A. Bootsma, R. H. Hesslein, W. L. Lockhart, and R. E. Hecky. 2003. Mercury concentrations in the food web of Lake Malawi, East Africa. Journal of Great Lakes Research 29:258-266.

LDEQ (Louisiana Department of Environmental Quality). 2005. Summary of issues related to mercury contamination of fish. Available: www.deq.louisiana.gov/portal/ default.aspx?tabid=1637. (August 2006).

Lee, Y. H., K. H. Bishop, J. Munthe, A. Iverfeldt, M. Verta, H. Parkman, and H. Hultberg. 1998. An examination of current $\mathrm{Hg}$ deposition and export in Fenno-Scandian catchments. Biogeochemistry 40:125-135.

Leibold, M. A., J. M. Chase, J. B. Shurin, and A. M. Downing. 1997. Species turnover and the regulation of trophic structure. Annual Review of Ecology and Systematics 28:467-494.

Lindqvist, O., K. Johansson, M. Aastrup, A. Anderson, L. Bringmark, G. Hovsenius, L. Hakanson, A. Iverfeldt, M. Meili, and B. Timm. 1991. Mercury in the Swedish environment-recent research on causes, consequences and corrective measures: 11. Mercury in forest lake ecosystems - bioavailability, bioaccumulation, and biomagnification. Water, Air, and Soil Pollution 55:131157.

McClain, W. C., M. M. Chumchal, R. W. Drenner, and L. W. Newland. 2006. Mercury concentrations in fish from Lake Meredith, Texas: implications for the issuance of fish consumption advisories. Environmental Monitoring and Assessment 123:249-258.

Mesing, C. L., and A. M. Wicker. 1986. Home range, spawning migrations, and homing of radio-tagged Florida largemouth bass in two central Florida lakes. Transactions of the American Fisheries Society 115:286295.

Miles, C. J., H. A. Moye, E. J. Phillips, and B. Sargent. 2001. Partitioning of monomethylmercury between freshwater algae and water. Environmental Science and Technology 35:4277-4282.

Miller, P. J., and C. Van Atten. 2004. North American power plant emissions. Commission for Environmental Cooperation of North America, Montreal.

Minagawa, M., and E. Wada. 1984. Stepwise enrichment of 
${ }^{15} \mathrm{~N}$ along food chains: further evidence and the relation between $\delta^{15} \mathrm{~N}$ and animal age. Geochimica et Cosmochimica Acta 48:1135-1140.

Mitsch, W. J., and J. G. Gosselink. 2000. Wetlands, 3rd edition. Wiley, New York.

Morel, F. M. M., A. M. L. Kraepiel, and M. Amyot. 1998. The chemical cycle and bioaccumulation of mercury. Annual Review of Ecology and Systematics 29:543-566.

Munn, M. D., and T. M. Short. 1997. Spatial heterogeneity of mercury bioaccumulation by walleye in Franklin D. Roosevelt Lake and the upper Columbia River, Washington. Transactions of the American Fisheries Society 126:477-487.

Munthe, J., R. A. Bodaly, B. A. Branfireun, C. T. Driscoll, C. C. Gilmour, R. Harris, M. Horvat, M. Lucotte, and O. Malm. 2007. Recovery of mercury-contaminated fisheries. Ambio 36:33-44.

NADP (National Atmospheric Deposition Program). 2005. National Atmospheric Deposition Program 2004 annual summary. NADP, Data Report 2005-01, Champaign.

NRC (National Research Council). 2000. Toxicological effects of methylmercury. National Academy Press, Washington, D.C.

Pacyna, E. G., and J. M. Pacyna. 2002. Global emission of mercury from anthropogenic sources in 1995. Water, Air, and Soil Pollution 137:149-165.

Paller, M. H., C. H. Jagoe, H. Bennett, H. A. Brant, and J. A. Bowers. 2004. Influence of methylmercury from tributary streams on mercury levels in Savannah River Asiatic clams. Science of the Total Environment 325:209-219.

Post, D. M. 2002. Using stable isotopes to estimate trophic position: models, methods, and assumptions. Ecology 83:703-718.

Post, D. M., M. L. Pace, and N. J. Hairston, Jr. 2000. Ecosystem size determines food-chain length in lakes. Nature (London) 405:1047-1049.

Power, M., G. M. Klein, K. R. R. A. Guiguer, and M. K. H. Kwan. 2002. Mercury accumulation in the fish community of a sub-Arctic lake in relation to trophic position and carbon sources. Journal of Applied Ecology 39:819830.

Quinn, G. P., and M. J. Keough. 2002. Experimental design and data analysis for biologists. Cambridge University Press, Cambridge, UK.

Rodgers, D. W. 1996. Methylmercury accumulation by reservoir fish: bioenergetic and trophic effects. Pages 107-118 in L. E. Miranda and D. R. DeVries, editors. Multidimensional approaches to reservoir fisheries management. American Fisheries Society, Bethesda, Maryland.

Sammons, S. M., and M. J. Maceina. 2005. Activity patterns of largemouth bass in a subtropical U.S. reservoir. Fisheries Management and Ecology 12:331-339.

Schuster, P. F., D. P. Krabbenhoft, D. L. Naftz, L. D. Cecil, M. L. Olson, J. F. Dewild, D. D. Susong, J. R. Green, and M. L. Abbott. 2002. Atmospheric mercury deposition during the last 270 years: a glacial ice core record of natural and anthropogenic sources. Environmental Science and Technology 36:2303-2310.

Simoneau, M., M. Lucotte, S. Garceau, and D. Laliberte. 2005. Fish growth rates modulate mercury concentrations in walleye (Sander vitreus) from eastern Canadian lakes. Environmental Research 98:73-82.

Sorensen, J. A., L. W. Kallemeyn, and M. Sydor. 2005. Relationship between mercury accumulation in youngof-the-year yellow perch and water-level fluctuations. Environmental Science and Technology 39:9237-9243.

Stafford, C. P., and T. A. Haines. 2001. Mercury contamination and growth rate in two piscivore populations. Environmental Toxicology and Chemistry 20:2099_ 2101.

Stafford, C. P., B. Hansen, and J. A. Stanford. 2004. Mercury in fishes and their diet items from Flathead Lake, Montana. Transactions of the American Fisheries Society 133:349-357.

St. Louis, V. L., J. W. M. Rudd, C. A. Kelly, K. G. Beaty, N. S. Bloom, and R. J. Flett. 1994. Importance of wetlands as sources of methyl mercury to boreal forest ecosystems. Canadian Journal of Fisheries and Aquatic Sciences 51:1065-1076.

Swain, E. B., D. R. Engstrom, M. E. Brigham, T. A. Henning, and P. L. Brezonik. 1992. Increasing rates of atmospheric mercury deposition in midcontinental North America. Science 257:784-787.

TDSHS (Texas Department of State Health Services). 1995. B.A. Steinhagen Reservoir, Sam Rayburn Reservoir, Big Cypress Creek, Toledo Bend Reservoir and Caddo Lake ADV-12. TDSHS, Austin. Available: www.tdh.state.tx. us/bfds/ssd. (August 2006).

TDSHS (Texas Department of State Health Services). 1999. Public health assessment-Longhorn Army Ammunition Plant, Karnack, Harrison County, Texas. TDSHS, Austin. Available: www.atsdr.cdc.gov/HAC/PHA/ longhorn/laa_toc.html. (August 2006).

Tsui, M. T. K., and W. X. Wang. 2004. Uptake and elimination routes of inorganic mercury and methylmercury in Daphnia magna. Environmental Science and Technology 38:808-816.

Ullrich, S. M., T. W. Tanton, and S. A. Abdrashitova. 2001. Mercury in the aquatic environment: a review of factors affecting methylation. Critical Reviews in Environmental Science and Technology 31:241-293.

USACE (U.S. Army Corps of Engineers). 2007. Historical reservoir reports. USACE, Fort Worth District Reservoir Control Office, Fort Worth, Texas. Available:155.84.70. 101/reports2.htm. (June 2007).

USEPA (U.S. Environmental Protection Agency). 1998. Method 7473: mercury in solids and solutions by thermal decomposition, amalgamation, and atomic absorption spectrophotometry. USEPA, Washington, D.C.

USEPA (U.S. Environmental Protection Agency). 2000. Guidance for assessing chemical contaminant data for use in fish advisories. USEPA, Washington, D.C. Available: www.epa.gov/waterscience/fishadvice/ volume1/index.html. (June 2007).

Van Kley, J. E., and D. N. Hine. 1998. The wetland vegetation of Caddo Lake. Texas Journal of Science 50:267-290.

Vernberg, F. J., and S. Piyatiratitivorakul. 1998. Effect of salinity and temperature on the bioenergetics of adult stages of the grass shrimp (Palaemonetes pugio Holthuis) from the North Inlet estuary, South Carolina. Estuaries 21:176-193.

Warden, R. L., Jr., and W. J. Lorio. 1975. Movements of 
largemouth bass (Micropterus salmoides) in impounded water as determined by underwater telemetry. Transactions of the American Fisheries Society 104:696-702.

Warner, K. A., J. C. J. Bonzongo, E. E. Roden, G. M. Ward, A. C. Green, I. Chaubey, W. B. Lyons, and D. A. Arrington. 2005. Effect of watershed parameters on mercury distribution in different environmental compartments in the Mobile Alabama River basin, USA. Science of the Total Environment 347:187-207.

Wiener, J. G., D. P. Krabbenhoft, G. H. Heinz, and A. M. Scheuhammer. 2003. Ecotoxicology of mercury. Pages
409-463 in D. J. Hoffman, B. A. Rattner, G. A. Burton, Jr., and J. Cairns, Jr., editors. Handbook of ecotoxicology, 2nd edition. Lewis Publishers, Boca Raton, Florida. Wilson, J. 2003. Occurrence of and trends in selected sediment-associated contaminants in Caddo Lake, east Texas, 1940-2002. U.S. Geological Survey, Water Resources Investigations Report 03-4253, Austin, Texas. Zillioux, E. J., D. B. Porcella, and J. M. Benoit. 1993. Mercury cycling and effects in freshwater wetland ecosystems. Environmental Toxicology and Chemistry 12:2245-2264. 